\title{
ansa-Metallocene derivatives
}

\section{XVI * Chiral titanocene and zirconocene derivatives with symmetrically substituted, tetramethylethanediyl-bridged ligand frameworks. Crystal structures of representative examples}

\author{
Stephan Gutmann, Peter Burger, Hans-Ulrich Hund, Josef Hofmann \\ and Hans-Herbert Brintzinger **, \\ Fakultät für Chemie, Universität Konstanz, D-7750 Konstanz (F.R.G.)
}

\begin{abstract}
Syntheses of disubstituted, tetramethylethanediyl-bridged titanocene derivatives $\left(\mathrm{CH}_{3}\right)_{4} \mathrm{C}_{2}\left(1-\mathrm{C}_{5} \mathrm{H}_{3}-3-\mathrm{R}\right)_{2} \mathrm{TiCl}_{2}$, with $\mathrm{R}=\mathrm{t}$-butyl, trimethylsilyl, isopropyl, $\alpha, \alpha$-dimethylbenzyl and 1-phenylcyclohexyl, by reductive coupling of the appropriately substituted 6,6-dimethylpentafulvenes with $\mathrm{Mg} / \mathrm{CCl}_{4}$ and reaction of the resulting di-Grignard compounds with $\mathrm{TiCl}_{3} \cdot 3 \mathrm{THF}$ are described along with those of several zirconium analogues. The reaction sequence in each case gives, together with the desired racemate, comparable amounts of the corresponding meso-configurated complex. The NMR data for the racemic and meso diastereomers of these compounds and crystal structures of one meso and several racemic representatives are reported.
\end{abstract}

\section{Introduction}

Chiral ansa-metallocene derivatives of Group IV transition metals are of considerable current interest as catalysts for the stereospecific polymerization of $\alpha$ olefins [2-7]. So far, however, only complexes with bridged bis-indenyl and bis(tetrahydroindenyl) ligand frameworks $[8,9]$ have been reported. Since the stereoselectivities of these polymerization catalysts must have their origin in steric interactions between the substituted olefin and the chiral ligand framework, it would be desirable to extend the range of available chiral ansa-metallocene catalysts to types

* For part XV see ref. 1.

** To whom correspondence should be addressed. 
with other, e.g. sterically more demanding, substituents. In this communication we report on a synthesis, via a simple reductive coupling [10] of $\beta$-substituted fulvenes, of novel ansa-titanocene and ansa-zirconocene derivatives containing a tetramethylethanediyl bridge and sterically-demanding substituents at the $\beta$-positions of both of the ring ligands. We had hoped that the tendency of sufficiently bulky substituents to stay at maximum distance from each other would suppress the undesirable concurrent formation of achiral, meso-configurated products in which both substituents are placed at the same side of the ansa-metallocene molecule [8].

\section{Results and discussion}

Reductive coupling of a series of $\beta$-alkyl substituted 6,6-dimethylpentafulvenes with $\mathrm{Mg}$ metal and $\mathrm{CCl}_{4}[10]$ gave the symmetrically substituted, tetramethylethanediyl-bridged bis(3-alkylcyclopentadienylmagnesium chloride) derivatives 1-6, free of positional isomers, in ca. 25-30\% yield, according to Scheme 1.

Reactions of these di-Grignard derivatives with stoichiometric amounts of $\mathrm{TiCl}_{3} \cdot 3 \mathrm{THF}$ and subsequent oxidation with $\mathrm{HCl}$ in air afforded the disubstituted ansa-titanocene derivatives $1-\mathrm{TiCl}_{2}$ to $6-\mathrm{TiCl}_{2}$ in about $40-50 \%$ yield. The analogous ansa-zirconocene derivatives $1-\mathrm{ZrCl}_{2}$ and $2-\mathrm{ZrCl}_{2}$ were obtained in $20-30 \%$ yield by reaction of the appropriate di-Grignard compound with $\mathrm{ZrCl}_{4}$ in refluxing THF and subsequent extraction with pentane or diethyl ether.

The ${ }^{1} \mathrm{H}$ NMR spectra of these reaction products revealed that racemic and meso isomers of the respective ansa-metallocene dichlorides had been formed in comparable quantities. Fractional crystallisation from pentane or diethyl ether allowed separation of most of the isomer pairs (see Experimental section). The racemic and meso diastereomers were identified, after conversion to the dimethyl derivative with excess $\mathrm{LiCH}_{3}$, by observation of one or two metal- $\mathrm{CH}_{3}{ }^{1} \mathrm{H}$ NMR signals, respectively, and, in several cases, by crystal structure determinations.
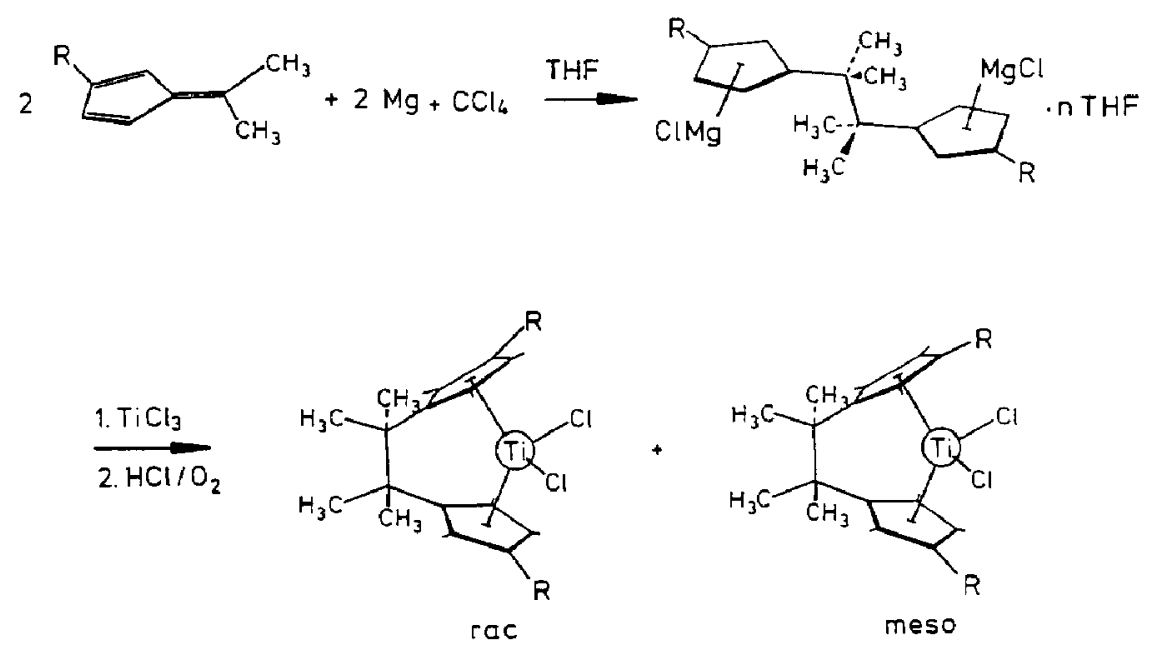

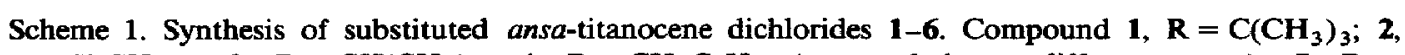
$\mathrm{R}=\mathrm{Si}\left(\mathrm{CH}_{3}\right)_{3} ; 3, \quad \mathrm{R}=\mathrm{CH}\left(\mathrm{CH}_{3}\right)_{2} ; 4, \quad \mathrm{R}=\mathrm{CH}_{2} \mathrm{C}_{6} \mathrm{H}_{5}$ (prepared by a different route); 5, $\mathrm{R}=$ $\mathrm{C}\left(\mathrm{CH}_{3}\right)_{2} \mathrm{C}_{6} \mathrm{H}_{5}$; and 6, $\mathrm{R}=\mathrm{C}\left(\mathrm{CH}_{2}\right)_{5} \mathrm{C}_{6} \mathrm{H}_{5}$. 
Table 1

${ }^{1} \mathrm{H}$ NMR data for the tetramethylethanediyl-bridged metallocenes 1- $\mathrm{TiCl}_{2}, 1-\mathrm{ZrCl}_{2}, 2-\mathrm{TiCl}_{2}, 2-\mathrm{ZrCl}_{2}, 3-\mathrm{TiCl}_{2}, 4-\mathrm{TiCl}_{2}, 5-\mathrm{TiCl}_{2}$ and 6- $\mathrm{TiCl}_{2}$, in $\mathrm{C}_{6} \mathrm{D}_{6}$ solution at room temperature, $\delta$ in ppm, at $250 \mathrm{MHz}(\mathrm{s}=$ singlet, $\mathrm{d}=$ doublet with $J(\mathrm{H}, \mathrm{H}) 6.8 \mathrm{~Hz}, \mathrm{t}=$ pseudotriplet with $J(\mathrm{H}, \mathrm{H}) \approx 3 \mathrm{~Hz}$, dd $=$ doublet of doublets with $J(\mathrm{H}, \mathrm{H}) \approx 3.4$ and $2.4 \mathrm{~Hz}$, sp = septet with $J(\mathrm{H}, \mathrm{H}) 6.8 \mathrm{~Hz})$

\begin{tabular}{|c|c|c|c|c|c|c|c|c|c|c|}
\hline \multicolumn{2}{|c|}{$1-\mathrm{TiCl}_{2}\left(\mathrm{R}=\mathrm{C}\left(\mathrm{CH}_{3}\right)_{3}\right)$} & \multicolumn{2}{|c|}{$1-\mathrm{ZrCl}_{2}\left(\mathrm{R}=\mathrm{C}\left(\mathrm{CH}_{3}\right)_{3}\right)$} & \multicolumn{2}{|c|}{$2-\mathrm{TiCl}_{2}\left(\mathrm{R}=\mathrm{Si}\left(\mathrm{CH}_{3}\right)_{3}\right)$} & \multicolumn{2}{|c|}{$2-\mathrm{ZrCl}_{2}\left(\mathrm{R}=\mathrm{Si}\left(\mathrm{CH}_{3}\right)_{3}\right)$} & \multicolumn{2}{|c|}{$3-\mathrm{TiCl}_{2}\left(\mathrm{R}=\mathrm{CH}\left(\mathrm{CH}_{3}\right)_{2}\right)$} & \multirow[t]{2}{*}{ Assignment } \\
\hline rac & meso & rac & meso & $\mathrm{rac}$ & meso & rac & meso & rac & meso & \\
\hline & & & & $0.45(\mathrm{~s}, 18)$ & $0.53(\mathrm{~s}, 18)$ & $0.43(s, 18)$ & $0.45(\mathrm{~s}, 18)$ & & & 3-Si $\left(\mathrm{CH}_{3}\right)_{3}$ \\
\hline $0.93(\mathrm{~s}, 6)$ & $0.92(\mathrm{~s}, 6)$ & $1.01(s, 6)$ & $0.99(s, 6)$ & $0.90(s, 6)$ & $0.89(s, 6)$ & $0.89(s, 6)$ & $0.98(s, 6)$ & $0.93(s, 6)$ & $0.86(s, 6)$ & $1.1^{\prime}-\mathrm{C}_{2}\left(\mathrm{CH}_{3}\right)_{4}$ \\
\hline $0.99(s, 6)$ & $0.99(s, 6)$ & $1.03(s, 6)$ & $1.03(s, 6)$ & $0.97(s, 6)$ & $0.96(s, 6)$ & $1.08(s, 6)$ & $1.01(s, 6)$ & $0.95(s, 6)$ & $0.99(s, 6)$ & $1,1^{\prime} \cdot \mathrm{C}_{2}\left(\mathrm{CH}_{3}\right)_{4}$ \\
\hline \multirow[t]{4}{*}{$1.44(\mathrm{~s}, 18)$} & $1.52(\mathrm{~s}, 18)$ & $1.40(s, 18)$ & $1.45(\mathrm{~s}, 18)$ & & & & & & & $3-\mathrm{C}\left(\mathrm{CH}_{3}\right)_{3}$ \\
\hline & & & & & & & & $1.13(\mathrm{~d}, 6)$ & $1.19(\mathrm{~d}, 6)$ & $3-\mathrm{CH}\left(\mathrm{CH}_{3}\right)_{2}$ \\
\hline & & & & & & & & $1.34(\mathrm{~d}, 6)$ & $1.43(\mathrm{~d}, 6)$ & 3. $\mathrm{CH}\left(\mathrm{CH}_{3}\right)_{2}$ \\
\hline & & & & & & & & $3.55(\mathrm{sp}, 2)$ & $3.69(\mathrm{sp}, 2)$ & 3- $\mathrm{CH}\left(\mathrm{CH}_{3}\right)_{2}$ \\
\hline $6.08(t, 2)$ & $5.99(t, 2)$ & $5.93(t, 2)$ & $5.86(t, 2)$ & $6.20(t, 2)$ & $6.05(t, 2)$ & $6.06(t, 2)$ & $6.00(t, 2)$ & $5.73(t, 2)$ & $5.66(t, 2)$ & $\alpha-\mathrm{C}_{5} \mathrm{H}_{3}$ \\
\hline $6.12(t, 2)$ & $6.05(t, 2)$ & $5.95(1,2)$ & $6.01(t, 2)$ & $6.22(t, 2)$ & $6.30(t, 2)$ & $6.08(t, 2)$ & $6.25(t, 2)$ & $5.86(t, 2)$ & $5.98(t, 2)$ & $\alpha-\mathrm{C}_{5} \mathrm{H}_{3}$ \\
\hline $6.57(\mathrm{dd}, 2)$ & $6.72(\mathrm{dd}, 2)$ & $6.48(\mathrm{dd}, 2)$ & $6.56(\mathrm{dd}, 2)$ & $6.90(\mathrm{dd}, 2)$ & $6.99(\mathrm{dd}, 2)$ & $6.82(t, 2)$ & $6.84(t, 2)$ & $6.64(t, 2)$ & $6.65(t, 2)$ & $\beta-\mathrm{C}_{5} \mathrm{H}_{3}$ \\
\hline
\end{tabular}

\begin{tabular}{|c|c|c|c|c|c|c|}
\hline \multicolumn{2}{|c|}{ 4- $\mathrm{TiCl}_{2}\left(\mathrm{R}=\mathrm{CH}_{2} \mathrm{C}_{6} \mathrm{H}_{5}\right)$} & \multicolumn{2}{|c|}{$5-\mathrm{TiCl}_{2}\left(\mathrm{R}=\mathrm{C}\left(\mathrm{CH}_{3}\right)_{2} \mathrm{C}_{6} \mathrm{H}_{5}\right)$} & \multicolumn{2}{|c|}{$6-\mathrm{TiCl}_{2}\left(\mathrm{R}=\mathrm{C}\left(\mathrm{CH}_{2}\right)_{5} \mathrm{C}_{6} \mathrm{H}_{5}\right)$} & \multirow[t]{2}{*}{ Assignment } \\
\hline rac & meso & rac & meso & rac & meso & \\
\hline $0.75(\mathrm{~s}, 6)$ & $0.72(s, 6)$ & $0.84(s, 6)$ & $0.93(\mathrm{~s}, 12)$ & $0.79(s, 6)$ & $0.79(s, 6)$ & $1,1^{\prime}-\mathrm{C}_{2}\left(\mathrm{CH}_{3}\right)_{4}$ \\
\hline $0.83(s, 6)$ & $0.86(s, 6)$ & $0.91(s, 6)$ & & $0.90(s, 6)$ & $0.90(s, 6)$ & $1.1^{\prime}-\mathrm{C}_{2}\left(\mathrm{CH}_{3}\right)_{4}$ \\
\hline \multirow[t]{5}{*}{$4.26(s, 4)$} & $4.48(s, 4)$ & & & & & 3- $\mathrm{CH}_{2} \mathrm{C}_{6} \mathrm{H}_{5}$ \\
\hline & & $1.91(s, 6)$ & $2.08(s, 6)$ & & & 3- $\mathrm{C}\left(\mathrm{CH}_{3}\right)_{2} \mathrm{C}_{6} \mathrm{H}_{5}$ \\
\hline & & $2.109 \mathrm{~s}, 6)$ & $2.21(\mathrm{~s}, 6)$ & & & 3- $\mathrm{C}\left(\mathrm{CH}_{3}\right)_{2} \mathrm{C}_{6} \mathrm{H}_{5}$ \\
\hline & & & & 1.35 to $1.68(\mathrm{~m}, 12)$ & 1.35 to $1.68(\mathrm{~m}, 12)$ & 3-C $\left(\mathrm{CH}_{2}\right)_{5} \mathrm{C}_{6} \mathrm{H}_{5}$ \\
\hline & & & & 2.65 to $2.87(\mathrm{~m}, 8)$ & 2.65 to $2.87(\mathrm{~m}, 8)$ & $3-\mathrm{C}\left(\mathrm{CH}_{2}\right)_{5} \mathrm{C}_{6} \mathrm{H}_{5}$ \\
\hline $5.69(t, 2)$ & $5.75(t, 2)$ & $6.11(t, 2)$ & $5.85(\mathrm{t}, 2)$ & $6.07(t, 2)$ & $5.83(t, 2)$ & $\alpha-\mathrm{C}_{5} \mathrm{H}_{3}$ \\
\hline $5.84(t, 2)$ & $5.90(t, 2)$ & $6.18(t, 2)$ & $6.21(t, 2)$ & $6.16(t, 2)$ & $6.19(\mathrm{t}, 2)$ & $\alpha-\mathrm{C}_{5} \mathrm{H}_{3}$ \\
\hline $6.61(t, 2)$ & $6.55(t, 2)$ & $6.55(\mathrm{dd}, 2)$ & $6.59(\mathrm{dd}, 2)$ & $6.51(\mathrm{dd}, 2)$ & $6.63(\mathrm{dd}, 2)$ & $\beta-C_{5} H_{3}$ \\
\hline 6.98 to $7.26(\mathrm{~m}, 10)$ & 6.98 to $7.26(\mathrm{~m}, 10)$ & 6.95 to $7.12(\mathrm{~m}, 10)$ & 6.95 to $7.12(\mathrm{~m}, 10)$ & 6.95 to $7.35(\mathrm{~m}, 10)$ & 6.95 to $7.35(\mathrm{~m}, 10)$ & $3-\mathrm{C}\left(\mathrm{CH}_{x}\right)_{y} \mathrm{C}_{6} \mathrm{H}_{5}$ \\
\hline
\end{tabular}



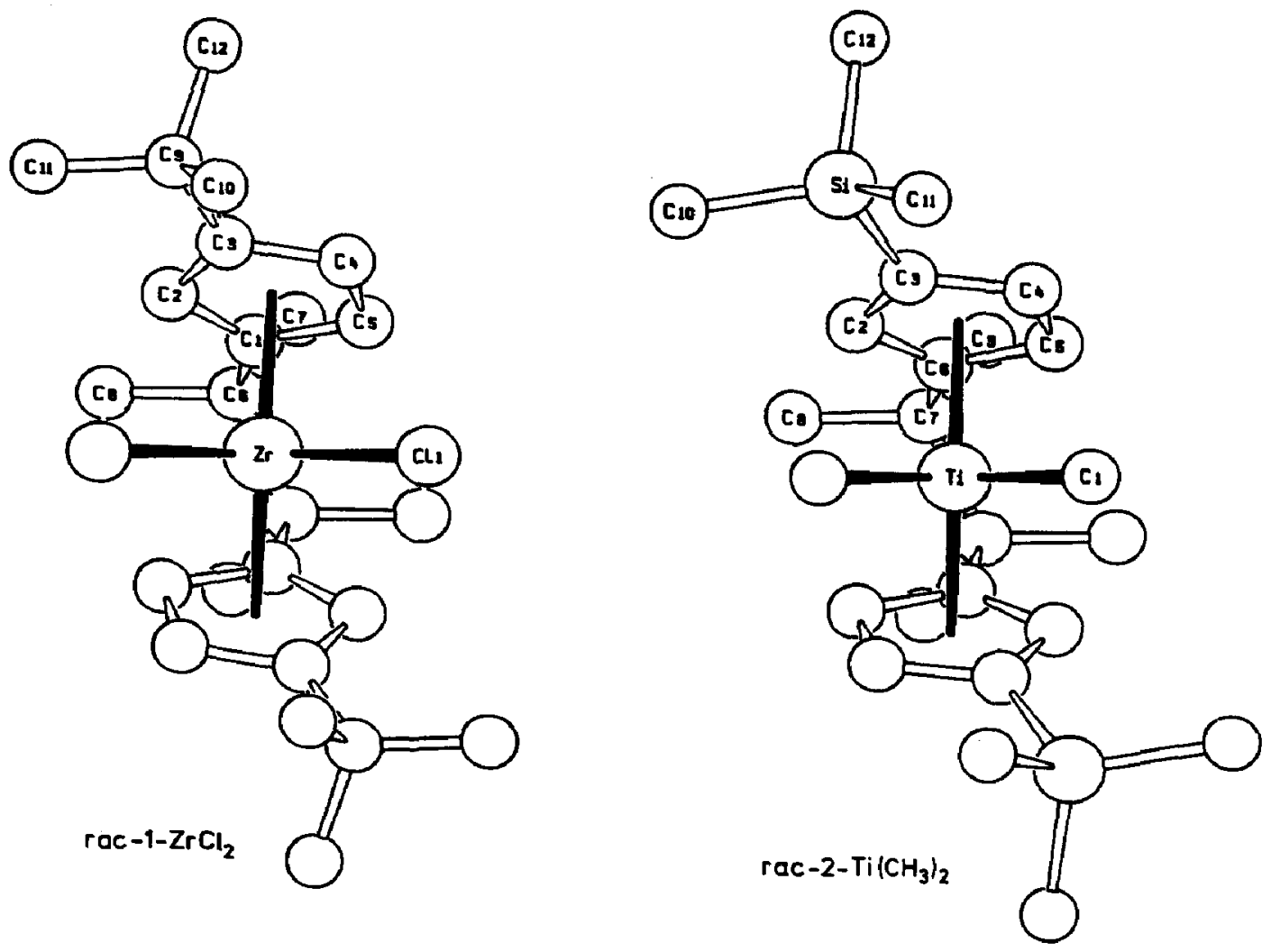

Fig. 1. Axially symmetric structures of $R, S-\left(\mathrm{CH}_{3}\right)_{4} \mathrm{C}_{2}\left(1-\mathrm{C}_{5} \mathrm{H}_{3}-3-\mathrm{C}\left(\mathrm{CH}_{3}\right)_{3}\right)_{2} \mathrm{ZrCl}_{2}$ (rac-1-ZrCl${ }_{2}$, left) and of $R, S-\left(\mathrm{CH}_{3}\right)_{4} \mathrm{C}_{2}\left(1-\mathrm{C}_{5} \mathrm{H}_{3}-3-\mathrm{Si}\left(\mathrm{CH}_{3}\right)_{3}\right)_{2} \mathrm{Ti}\left(\mathrm{CH}_{3}\right)_{2}$ (rac-2- $\mathrm{Ti}\left(\mathrm{CH}_{3}\right)_{2}$, right); projections parallel to molecular $C_{2}$ axis.

All the complexes studied in this series give rise to pairwise identical ${ }^{1} \mathrm{H}$ NMR signals for corresponding protons of their two ligand moieties; both the racemic and the meso isomers of each complex must thus possess, on the NMR time scale, the expected axial or planar symmetry.

Three cyclopentadienyl proton signals are apparent for each of the substituted ansa-metallocene dichlorides in $\mathrm{C}_{6} \mathrm{D}_{6}$ solution, two at $5.6-6.3 \mathrm{ppm}$ and one at $6.5-7.0 \mathrm{ppm}$. The method of preparation of these complexes from $\beta$-substituted fulvenes (and the results of the X-ray diffraction studies of several representative examples) show that the alkyl substituent is located in one of the $\beta$-positions of the $\mathrm{C}_{5}$ ring; the single low-field resonance at $6.5-7.0 \mathrm{ppm}$ must thus be due to the remaining $\beta$-protons, while the two resonances at $5.6-6.3 \mathrm{ppm}$ are to be assigned to the two pairs of $\alpha$-protons * As a general and diagnostically useful rule, these $\alpha-H$ signals were found to lie closer together for the racemic than for the meso isomer for all compounds studied in this series.

Some of these complexes, rac-1- $\mathrm{ZrCl}_{2}$, rac-2- $\mathrm{Ti}\left(\mathrm{CH}_{3}\right)_{2}$, meso-2- $\mathrm{TiCl}_{2}$ and rac-6$\mathrm{TiCl}_{2}$, were obtained in the form of crystals suitable for structure determination by

\footnotetext{
* This assignment is contrary to that previously made for related ansa-metallocenes $[11,21]$.
} 

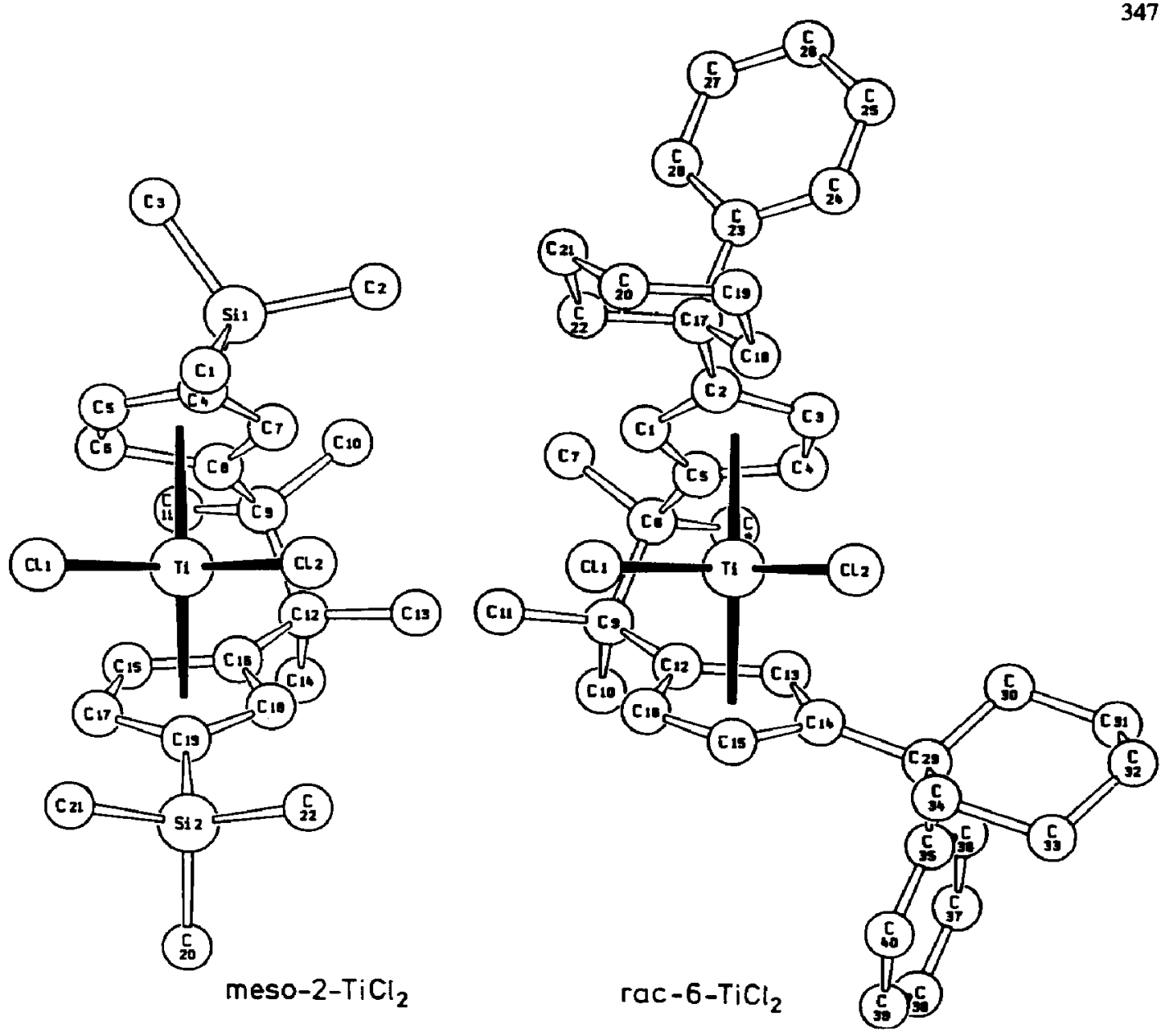

Fig. 2. Asymmetric structures of meso- $\left(\mathrm{CH}_{3}\right)_{4} \mathrm{C}_{2}\left(1-\mathrm{C}_{5} \mathrm{H}_{3}-\mathrm{Si}\left(\mathrm{CH}_{3}\right)_{3}\right)_{2} \mathrm{TiCl}_{2}$ (meso-2-TiCl 2 , left) and of $R, S-\left(\mathrm{CH}_{3}\right)_{4} \mathrm{C}_{2}\left(1-\mathrm{C}_{5} \mathrm{H}_{3}-3-\mathrm{C}\left(\mathrm{CH}_{2}\right)_{5} \mathrm{C}_{6} \mathrm{H}_{5}\right)_{2} \mathrm{TiCl}_{2}$ (rac-6-TiCl 2 , right); projections parallel to centroid-metal-centroid bisector axis.

X-ray diffraction. The resulting structures (see Fig. 1 and 2, Tab. 2-5) confirm the ${ }^{1} \mathrm{H}$ NMR assignments discussed above. The structures of the racemic isomers of 1- $\mathrm{ZrCl}_{2}$ and 2-Ti( $\left(\mathrm{CH}_{3}\right)_{2}$ show the expected axial symmetry (Fig. 1).

The meso isomer of $2-\mathrm{TiCl}_{2}$ (Fig. 2), on the other hand, has a similarly asymmetric arrangement of the tetramethylethanediyl bridge, as was previously observed for the meso isomer of the ethanediyl-bridged bis(tetrahydroindenyl)titanium dichloride [8]. While the two ring ligands are not equivalent in the crystal structure of this complex, a rotation of each $\mathrm{C}_{5}$ ring about the metal-centroid axis by ca. $15^{\circ}$ is sufficient to convert the structure represented in Fig. 2 into its mirror image. This interconversion must be fast in solution for all the meso complexes studied, as indicated by their symmetrically equivalent ${ }^{1} \mathrm{H}$ NMR spectra.

Surprisingly, the racemate of $6-\mathrm{TiCl}_{2}$ also has a completely asymmetric structure. In this complex, which is sterically highly encumbered, the approximate $C_{2}$ symmetry axis of the disubstituted ligand framework is misaligned by ca. $30^{\circ}$ relative to the $\mathrm{TiCl}_{2}$ bisector axis. A similar misalignment was apparent from a crystal 
Table 2

Bond lengths (in pm) and bond and dihedral angles (in degree) for complex rac-1- $\mathrm{ZrCl}_{2}$, rac$\left(\mathrm{CH}_{3}\right)_{4} \mathrm{C}_{2}\left(1-\mathrm{C}_{5} \mathrm{H}_{3}-3-\mathrm{C}\left(\mathrm{CH}_{3}\right)_{3}\right)_{2} \mathrm{ZrCl}_{2}$

\begin{tabular}{lllc}
\hline $\mathrm{Zr}-\mathrm{Cl}(1)$ & $244.7(1)$ & $\mathrm{Cl}(1)-\mathrm{Zr}-\mathrm{Cl}\left(1^{\prime}\right)$ & $100.0(1)$ \\
$\mathrm{Zr}-\mathrm{C}(1)$ & $249.3(3)$ & $\mathrm{CR}(1)-\mathrm{Zr}-\mathrm{CR}\left(1^{\prime}\right)^{a}$ & 124.8 \\
$\mathrm{Zr}-\mathrm{C}(2)$ & $251.4(4)$ & $\mathrm{PL}(1)-\mathrm{PL}\left(1^{\prime}\right)^{a}$ & 61.2 \\
$\mathrm{Zr}-\mathrm{C}(3)$ & $260.2(4)$ & $\mathrm{ZrCl}(1) \mathrm{Cl}\left(1^{\prime}\right)-\mathrm{ZrCR}(1) \mathrm{CR}\left(1^{\prime}\right)^{a}$ & 92.3 \\
$\mathrm{Zr}-\mathrm{C}(4)$ & $253.5(3)$ & & \\
$\mathrm{Zr}-\mathrm{C}(5)$ & $246.0(3)$ & $\mathrm{C}(6)-\mathrm{C}(1)-\mathrm{PL}(1)^{a}$ & $4.8($ exo $)$ \\
$\mathrm{Zr}-\mathrm{CR}(1)^{a}$ & 222.7 & $\mathrm{C}(9)-\mathrm{C}(3)-\mathrm{PL}(1)^{a}$ & 10.0 exo $)$
\end{tabular}

a $\mathrm{CR}=$ centroid, $\mathrm{PL}=$ mean plane of $\eta^{5}-\mathrm{C}_{5}$ ring.

Table 3

Bond lengths (in pm) and bond and dihedral angles (in degree) for complex rac-2-Ti( $\left(\mathrm{CH}_{3}\right)_{2}$, rac$\left(\mathrm{CH}_{3}\right)_{4} \mathrm{C}_{2}\left(1-\mathrm{C}_{5} \mathrm{H}_{3}-3-\mathrm{Si}\left(\mathrm{CH}_{3}\right)_{3}\right)_{2} \mathrm{Ti}\left(\mathrm{CH}_{3}\right)_{2}$

\begin{tabular}{lllc}
\hline $\mathrm{Ti}-\mathrm{C}(1)$ & $215.2(3)$ & $\mathrm{C}(1)-\mathrm{Ti}-\mathrm{C}\left(1^{\prime}\right)$ & $90.4(2)$ \\
$\mathrm{Ti}-\mathrm{C}(2)$ & $241.0(2)$ & $\mathrm{CR}(1)-\mathrm{Ti}-\mathrm{CR}\left(1^{\prime}\right)^{a}$ & 128.3 \\
$\mathrm{Ti}-\mathrm{C}(3)$ & $245.3(2)$ & $\mathrm{PL}(1)-\mathrm{PL}\left(1^{\prime}\right)^{a}$ & 53.8 \\
$\mathrm{Ti}-\mathrm{C}(4)$ & $241.2(2)$ & $\mathrm{TiC}(1) \mathrm{C}\left(1^{\prime}\right)-\mathrm{TiCR}(1) \mathrm{CR}\left(1^{\prime}\right)^{a}$ & 91.7 \\
$\mathrm{Ti}-\mathrm{C}(5)$ & $237.6(3)$ & & \\
$\mathrm{Ti}-\mathrm{C}(6)$ & $241.6(3)$ & $\mathrm{C}(7)-\mathrm{C}(6)-\mathrm{PL}(1)^{a}$ & $2.5($ exo $)$ \\
$\mathrm{Ti}^{a} \mathrm{CR}(1)^{a}$ & 209.3 & $\mathrm{Si}-\mathrm{C}(3)-\mathrm{PL}(1)^{a}$ & $11.7($ exo $)$
\end{tabular}

a $\mathrm{CR}=$ centroid, $\mathrm{PL}=$ mean plane at $\eta^{5}-\mathrm{C}_{5}$ ring.

Table 4

Bond lengths (in pm) and bond and dihedral angles (in degree) for complex meso-2- $\mathrm{TiCl}_{2}, \mathrm{meso}$ $\left(\mathrm{CH}_{3}\right)_{4} \mathrm{C}_{2}\left(1-\mathrm{C}_{5} \mathrm{H}_{3}-3-\mathrm{Si}\left(\mathrm{CH}_{3}\right)_{3}\right)_{2} \mathrm{TiCl}_{2}$

\begin{tabular}{lllc}
\hline Ti-Cl(1) & $235.4(1)$ & Ti-CR(1) $^{a}$ & 207.5 \\
Ti-Cl(2) & $233.9(1)$ & Ti-CR(2) $^{a}$ & 206.8 \\
Ti-C(4) & $244.5(4)$ & & \\
Ti-C(5) & $240.7(4)$ & $\mathrm{Cl}(1)-\mathrm{Ti}-\mathrm{Cl}(2)$ & $97.7(1)$ \\
$\mathrm{Ti}-\mathrm{C}(6)$ & $235.6(4)$ & $\mathrm{CR}(1)-\mathrm{Ti}-\mathrm{CR}(2)^{a}$ & 127.7 \\
$\mathrm{Ti}-\mathrm{C}(7)$ & $240.6(4)$ & $\mathrm{PL}(1)-\mathrm{PL}(2)^{a}$ & 56.9 \\
$\mathrm{Ti}-\mathrm{C}(8)$ & $239.3(4)$ & $\mathrm{TiCl}(1) \mathrm{Cl}(2)-\mathrm{TiCR}(1) \mathrm{CR}(2)^{a}$ & 90.2 \\
$\mathrm{Ti}-\mathrm{C}(15)$ & $236.2(4)$ & & \\
$\mathrm{Ti}-\mathrm{C}(16)$ & $234.9(4)$ & $\mathrm{C}(9)-\mathrm{C}(8)-\mathrm{PL}(1)^{a}$ & $2.3($ exo $)$ \\
$\mathrm{Ti}-\mathrm{C}(17)$ & $241.8(4)$ & $\mathrm{C}(12)-\mathrm{C}(16)-\mathrm{PL}(2)^{a}$ & $1.0($ exo $)$ \\
$\mathrm{Ti}-\mathrm{C}(18)$ & $239.9(4)$ & $\mathrm{Si}(1)-\mathrm{C}(4)-\mathrm{PL}(1)^{a}$ & $7.3($ exo $)$ \\
Ti-C(19) & $245.0(4)$ & $\mathrm{Si}(2)-\mathrm{C}(19)-\mathrm{PL}(2)^{a}$ & $9.2($ exo $)$ \\
\hline
\end{tabular}

${ }^{a} \mathrm{CR}=$ centroid, $\mathrm{PL}=$ mean plane of $\eta^{5}-\mathrm{C}_{5}$ ring.

structure analysis of racemic $2-\mathrm{TiCl}_{2}$; no satisfactory refinement was obtained in this case, however, possibly due to some kind of crystal disorder. The axially equivalent NMR signals * observed at room temperature in $\mathrm{C}_{6} \mathrm{D}_{6}$ solution for these as for all other racemic complexes in this series (Tab. 1), indicate that these

${ }^{*{ }^{13} \mathrm{C} \mathrm{NMR}}$ spectra with five sharp cyclopentadienyl carbon resonances in the range of $105-145 \mathrm{ppm}$ also show this pairwise equivalence. 
Table 5

Bond lengths (in pm) and bond and dihedral angles (in degree) for complex rac-6- $\mathrm{TiCl}_{2}$, rac$\left(\mathrm{CH}_{3}\right)_{4} \mathrm{C}_{2}\left(1-\mathrm{C}_{5} \mathrm{H}_{3}-3-\mathrm{C}\left(\mathrm{CH}_{2}\right)_{5} \mathrm{C}_{6} \mathrm{H}_{5}\right)_{2} \mathrm{TiCl}_{2}$

\begin{tabular}{|c|c|c|c|}
\hline $\mathrm{Ti}-\mathrm{Cl}(1)$ & $237.5(1)$ & Ti-CR(1) ${ }^{a}$ & 208.1 \\
\hline $\mathrm{Ti}-\mathrm{Cl}(2)$ & $231.5(1)$ & $\operatorname{Ti-CR(2)}{ }^{a}$ & 208.6 \\
\hline Ti-C(1) & $242.5(3)$ & & \\
\hline $\mathrm{Ti}-\mathrm{C}(2)$ & $251.4(3)$ & $\mathrm{Cl}(1)-\mathrm{Ti}-\mathrm{Cl}(2)$ & $94.0(1)$ \\
\hline Ti-C(3) & $241.4(3)$ & $\mathrm{CR}(1)-\mathrm{T} i-\mathrm{CR}(2)^{a}$ & 128.8 \\
\hline $\mathrm{Ti}-\mathrm{C}(4)$ & $232.7(3)$ & $\operatorname{PL}(1)-P L(2) a^{a}$ & 59.4 \\
\hline $\mathrm{Ti}-\mathrm{C}(5)$ & $235.9(3)$ & $\operatorname{TiCl}(1) \mathrm{Cl}(2)-\operatorname{TiCR}(1) \mathrm{CR}(2)^{a}$ & 90.1 \\
\hline $\mathrm{Ti}-\mathrm{C}(12)$ & $231.4(3)$ & & \\
\hline $\mathrm{Ti}-\mathrm{C}(13)$ & $237.2(3)$ & $C(6)-C(5)-P L(1)^{a}$ & $2.6($ exo $)$ \\
\hline Ti-C(14) & $250.8(3)$ & $\mathrm{C}(9)-\mathrm{C}(12)-\mathrm{PL}(2)^{a}$ & $0.6($ exo $)$ \\
\hline $\mathrm{Ti}-\mathrm{C}(15)$ & $244.5(3)$ & $\mathrm{C}(17)-\mathrm{C}(2)-\mathrm{PL}(1)^{a}$ & $7.9($ exo $)$ \\
\hline $\mathrm{Ti}-\mathrm{C}(16)$ & $237.6(3)$ & $\mathrm{C}(29)-\mathrm{C}(14)-\mathrm{PL}(2)^{a}$ & 11.3 (exo) \\
\hline
\end{tabular}

${ }^{a} \mathrm{CR}=$ Centroid, $\mathrm{PL}=$ mean plane of $\eta^{5}-\mathrm{C}_{5}$ ring.

tertiary-alkyl or trimethylsilyl substituted ansa-titanocene dihalide complexes undergo a fast fluctuation between the asymmetric geometry represented in Fig. 2 and that in which the conformations of the upper and lower ring ligands are interchanged; a rotation of both ring ligands about the metal-centroid axis by ca. $65^{\circ}$ is required to interconvert these two equivalent conformers.

Apparently, particularly pronounced repulsive interactions between bulky alkyl substituents and the chloride ligands can force the $\mathrm{TiCl}_{2}$ group out of its normal, axially symmetric equilibrium position. The release of steric strain in these non-symmetric structures is apparent from the different degrees of bending of the $\beta$-substituent out of the plane of the adjacent ring. In the axially symmetric species rac-1- $\mathrm{ZrCl}_{2}$ and rac-2-Ti( $\left(\mathrm{CH}_{3}\right)_{2}$, the bond between each of the t-butyl or trimethylsilyl groups to the adjacent ring atom deviates from the mean ring plane by $10-12^{\circ}$. In the asymmetric structure of rac-6- $\mathrm{TiCl}_{2}$, only one of the substituents (the one in distal conformation) suffers a comparable out-of-plane bending, while the other one (in central conformation) deviates from the adjacent ring plane by less than $8^{\circ}$.

In the meso-configurated isomer of $2-\mathrm{TiCl}_{2}$, finally, we observe for both trimethylsilyl substituents (both of which adopt central conformations) reduced out-of-plane angles of only $7-9^{\circ}$. This raises the unexpected possibility that the bulky ring substituents employed in this study may introduce a thermodynamic bias toward formation of the meso instead of the rac isomer: The conformer with both substituents in central position, which is available only for the meso product, appears better suited to avoid repulsive interactions between ring substituents and halide ligands than any of the conformers available for the racemic isomer. Other, presumably kinetic, factors affecting the stereochemical course of these ansa-metallocene formation reactions will be discussed in a subsequent communication [12].

\section{Experimental}

Unless otherwise stated, the following procedures were carried out under $\mathbf{N}_{2}$ or Ar, with solvents thoroughly dried and degassed.

Substituted cyclopentadiene derivatives $\mathrm{C}_{5} \mathrm{H}_{5} R$ with $R=$ t-butyl [13], isopropyl [14], and trimethylsilyl [15] were prepared as previously described. The $\alpha, \alpha$-dimeth- 
ylbenzyl and 1-phenylcyclohexyl substituted cyclopentadiene derivatives were obtained, in practically quantitative yield, as their lithium salts, by reaction of 6,6-dimethylfulvene and 6,6-pentamethylenefulvene (cf. ref. 16) with one equivalent of phenyllithium in diethyl ether $[17,18]$ and, after washing with pentane and drying in vacuo, used directly for subsequent condensations with acetone.

\section{2( $\beta$ )-Alkyl-substituted 6,6-dimethyl pentafulvenes}

The synthesis of 2-t-butyl-6,6-dimethylfulvene has been described before [19]. We prepared it and its isopropyl analogue by the pyrrolidine-induced condensation of the substituted cyclopentadiene derivatives with acetone, using the procedure described by Stone and Little [16]. Trimethylsilyl-6,6-dimethylfulvene was obtained, in $40-45 \%$ yield, by reaction of trimethylsilylcyclopentadienyllithium with acetone. These substituted fulvenes were purified by distillation at $45-55^{\circ} / 0.1$ torr to yield ${ }^{1} \mathrm{H}$ NMR spectroscopically pure products.

In the case of $\mathrm{R}=\alpha, \alpha$-dimethylbenzyl and 1-phenylcyclohexyl, the respective cyclopentadienyllithium salts were used for the pyrrolidine-induced condensation with acetone [16] to yield ca. 50-60\% of the substituted dimethylfulvenes, which were purified by filtering a diethyl ether/pentane solution through a short column of silica gel and subsequent crystallization at $-80^{\circ} \mathrm{C}$.

The ${ }^{1} \mathrm{H}$ NMR spectra of $\mathrm{C}_{6} \mathrm{D}_{6}$ solutions of these fulvenes (Tab. 6) show three vinylic proton resonances, of which two (a doublet of doublets and a pseudotriplet ${ }^{*}$ ) are well-resolved. The third vinylic resonance is broadened by coupling to the 6,6-dimethyl substituents, as shown by its resolution into a sharp doublet of doublets upon decoupling at the 6,6-dimethyl resonance. Previous studies have shown [20] that this long-range coupling involves the protons in 2-position of the fulvene ring; the presence of only one broadened resonance thus proves that one of the 2-positions is occupied by the alkyl substituent. An increase in intensity upon irradiation at the 6,6-( $\left(\mathrm{CH}_{3}\right)_{2}$ frequency, caused by the nuclear Overhauser effect, of the two initially sharp resonances further indicates that these are due to the two $\alpha$-protons.

\section{Synthesis of tetramethylethanediyl-bridged bis(cyclopentadienyl) derivatives}

The fulvene derivatives described above were reductively coupled with $\mathrm{Mg}$ metal and $\mathrm{CCl}_{4}$ by use of the procedure described in ref. 10 . Since the resulting, disubstituted di-Grignard compounds $\left(\mathrm{CH}_{3}\right)_{4} \mathrm{C}_{2}\left(\mathrm{C}_{5} \mathrm{H}_{3} \mathrm{RMgCl}\right)_{2} \cdot n$ THF were substantially more soluble in THF than the unsubstituted analogue [10], it proved necessary to replace much of the THF solvent after completion of the coupling reaction by diethyl ether to bring about precipitation of more of the product, which was subsequently washed with diethyl ether/pentane and dried in vacuo to yield the di-Grignard ligand derivatives in ca. 20-30\% theoretical yield.

The trimethylsilyl-substituted derivative was also obtained, as a colourless solid and in almost quantitative yield, by reaction of $\left(\mathrm{CH}_{3}\right)_{4} \mathrm{C}_{2}\left(\mathrm{C}_{5} \mathrm{H}_{4} \mathrm{MgCl}\right)_{2} \cdot 4 \mathrm{THF}$ [10] with an excess of $\left(\mathrm{CH}_{3}\right)_{3} \mathrm{SiCl}$ in THF, hydrolysis with aqueous $\mathrm{NaHCO}_{3}$, extraction with pentane, partial evaporation, and crystallization at $-80^{\circ} \mathrm{C}$. Its dilithium

\footnotetext{
* The presence of an $\alpha-\mathrm{H}$ atom in the isopropyl substituent causes an additional interaction with this
} $\alpha$-proton $(J(\mathrm{H}, \mathrm{H}) \approx 1.2 \mathrm{~Hz})$. 
Table 6

${ }^{1} \mathrm{H}$ NMR spectra of 2-substituted 6,6-dimethylpentafulvenes, in $\mathrm{C}_{6} \mathrm{D}_{6}$ at room temperature, $\delta$ in ppm at $250 \mathrm{MHz}(\mathrm{s}=$ singlet, $\mathrm{d}=$ doublet with $J(\mathrm{H}, \mathrm{H}) 6.7 \mathrm{~Hz}, \mathrm{t}=$ pseudotriplet with $J(\mathrm{H}, \mathrm{H}) \approx 2 \mathrm{~Hz}$, dd = doublet of doublets with $J(\mathrm{H}, \mathrm{H}) \approx 5.2$ and $2 \mathrm{~Hz}, \mathrm{sp}=$ septet with $J(\mathrm{H}, \mathrm{H})=6.7 \mathrm{~Hz}$ )

\begin{tabular}{|c|c|c|c|c|}
\hline $\begin{array}{l}2 \\
\left(\mathrm{R}=\mathrm{Si}\left(\mathrm{CH}_{3}\right)_{3}\right)\end{array}$ & $\begin{array}{l}3 \\
\left(\mathrm{R}=\mathrm{CH}\left(\mathrm{CH}_{3}\right)_{2}\right)\end{array}$ & $\begin{array}{l}\mathbf{5} \\
\left(\mathrm{R}=\mathrm{C}\left(\mathrm{CH}_{3}\right)_{2} \mathrm{C}_{6} \mathrm{H}_{5}\right.\end{array}$ & $\begin{array}{l}6 \\
\left(\mathrm{R}=\mathrm{C}\left(\mathrm{CH}_{2}\right)_{5} \mathrm{C}_{6} \mathrm{H}_{5}\right.\end{array}$ & Assignment \\
\hline $0.25(\mathrm{~s}, 9)$ & & & & $2-\mathrm{Si}\left(\mathrm{CH}_{3}\right)_{3}$ \\
\hline $1.78(\mathrm{~s}, 3)$ & $1.78(s, 3)$ & $1.77(\mathrm{~s}, 3)$ & $1.75(\mathrm{~s}, 3)$ & $\left.6,6-\mathrm{C}(\mathrm{CH})_{3}\right)_{2}$ \\
\hline \multirow[t]{6}{*}{$1.80(\mathrm{~s}, 3)$} & $1.79(\mathrm{~s}, 3)$ & $1.81(\mathrm{~s}, 3)$ & $1.79(\mathrm{~s}, 3)$ & $6,6-\mathrm{C}(\mathrm{CH})_{2}$ \\
\hline & $1.19(\mathrm{~d}, 6)$ & & & $2-\mathrm{CH}\left(\mathrm{CH}_{3}\right)_{2}$ \\
\hline & $2.67(\mathrm{sp}, 1)$ & & & $2-\mathrm{CH}\left(\mathrm{CH}_{3}\right)_{2}$ \\
\hline & & $1.56(s, 6)$ & & $2-\mathrm{C}\left(\mathrm{CH}_{3}\right)_{2} \mathrm{C}_{6} \mathrm{H}_{5}$ \\
\hline & & & 1.30 to $1.73(\mathrm{~m}, 6)$ & $2-\mathrm{C}\left(\mathrm{CH}_{2}\right)_{5} \mathrm{C}_{6} \mathrm{H}_{5}$ \\
\hline & & & 2.03 to $2.25(\mathrm{~m}, 4)$ & $2-\mathrm{C}\left(\mathrm{CH}_{2}\right)_{5} \mathrm{C}_{6} \mathrm{H}_{5}$ \\
\hline $6.82(t, 1)$ & $6.24(\mathrm{~m}, 1)$ & $6.38(t, 1)$ & $6.35(t, 1)$ & $1-\mathrm{C}_{5} \mathrm{H}_{3}$ \\
\hline $6.70(\mathrm{dd}, 1)$ & $6.51(\mathrm{dd}, 1)$ & $6.32(\mathrm{dd}, 1)$ & $6.40(\mathrm{dd}, 1)$ & $3-\mathrm{C}_{5} \mathrm{H}_{3}$ \\
\hline \multirow[t]{2}{*}{$6.60(\mathrm{dd}, 1)$} & $6.57(\mathrm{dd}, 1)$ & $6.49(\mathrm{dd}, 1)$ & $6.49(\mathrm{dd}, 1)$ & $4-\mathrm{C}_{5} \mathrm{H}_{3}$ \\
\hline & & 7.03 to $7.39(\mathrm{~m}, 5)$ & 7.05 to $7.43(\mathrm{~m}, 5)$ & $2-\mathrm{C}\left(\mathrm{CH}_{x}\right)_{y} \mathrm{C}_{6} \mathrm{H}_{5}$ \\
\hline
\end{tabular}

derivative was obtained by treatment with two molar equivalents of $n$-butyllithium in THF solution of $-80^{\circ} \mathrm{C}$. An essentially identical procedure with benzyl bromide instead of trimethylsilyl chloride gave tetramethylethanediylbis(benzylcyclopentadiene) as a yellowish oil which was converted into its dilithium salt and used for the following reactions without purification.

\section{Synthesis of $\left(\mathrm{CH}_{3}\right)_{4} \mathrm{C}_{2}\left(\mathrm{I}-\mathrm{C}_{5} \mathrm{H}_{3}-3-\mathrm{R}\right)_{2} \mathrm{TiCl}_{2}$}

As an example, we give details of the synthesis of the complex 1-TiCl 2 . THF (150 $\mathrm{ml}$ ) was condensed into a mixture of $7.1 \mathrm{~g}(9.7 \mathrm{mmol})$ of solid $\left(\mathrm{CH}_{3}\right)_{4} \mathrm{C}_{2}\left(1-\mathrm{C}_{5} \mathrm{H}_{3}-3-\right.$ $\left.\mathrm{C}\left(\mathrm{CH}_{3}\right)_{3} \mathrm{MgCl}\right)_{2} \cdot 4 \mathrm{THF}$ and $3.6 \mathrm{~g}(9.7 \mathrm{mmol})$ of solid $\mathrm{TiCl}_{3} \cdot 3 \mathrm{THF}$ at $-78^{\circ} \mathrm{C}$. The reaction mixture was allowed to warm to room temperature and stirred for 6 days. It was cooled to $-40^{\circ} \mathrm{C}$ and $10 \mathrm{ml}$ of $6 \mathrm{M}$ aqueous $\mathrm{HCl}$ were added. The mixture was then stirred under air for $5 \mathrm{~h}$ and the organic phase then separated and evaporated to dryness. The residue was taken up in $\mathrm{CH}_{2} \mathrm{Cl}_{2} /$ aqueous $\mathrm{HCl}$ and the solution stirred overnight, again under air. The organic layer was dried over anhydrous $\mathrm{MgSO}_{4}$ and evaporated to dryness. A small sample of the red crude product showed, in $\mathrm{C}_{6} \mathrm{D}_{6}$ solution, the ${ }^{1} \mathrm{H}$ NMR signals of both isomers (see Table 1) in a ratio of about 2.5/1. Treatment of this sample with an excess of $\mathrm{CH}_{3} \mathrm{Li}$ in diethyl ether gave the dimethyl derivatives and the presence of one $(0.25 \mathrm{ppm})$ and of two $(0.21$ and $0.31 \mathrm{ppm}) \mathrm{Ti}\left(\mathrm{CH}_{3}\right)_{2}$ in the ${ }^{1} \mathrm{H}$ NMR spectrum of the mixture showed that the major isomer was the desired rac-1- $\mathrm{TiCl}_{2}$ and the minor isomer meso-1- $\mathrm{TiCl}_{2}$. Recrystallisation of the crude product mixture from boiling methyl cyclohexane gave two fractions, of 1.3 and $0.7 \mathrm{~g}$ (total yield $46 \%$ ), of red crystals. The first fraction contained practically pure racemate, and the second both isomers in about equal amounts.

A closely similar reaction of $\left(\mathrm{CH}_{3}\right)_{4} \mathrm{C}_{2}\left(1-\mathrm{C}_{5} \mathrm{H}_{3}-3-\mathrm{C}\left(\mathrm{CH}_{3}\right)_{3} \mathrm{MgCl}\right)_{2} \cdot n$ THF with $\mathrm{TiCl}_{3} \cdot 3 \mathrm{THF}$, but carried out, for 5-6 hours under reflux, gave, after work-up as described above, $2.0 \mathrm{~g}$ (total yield $46 \%$ ) of crude product mixture containing the rac and meso isomers in a ratio of about $1 / 1$. Repeated crystallisation from diethyl 
ether at $-78^{\circ} \mathrm{C}$ yielded $0.28 \mathrm{~g}$ of ${ }^{1} \mathrm{H}$ NMR spectroscopically pure racemate. The products were identified as isomers $1-\mathrm{TiCl}_{2}$ from their ${ }^{1} \mathrm{H}$ NMR spectra (Tab. 1) and elemental analyses. Found: $\mathrm{C}, 65.39 ; \mathrm{H}, 8.28 . \mathrm{C}_{24} \mathrm{H}_{36} \mathrm{Cl}_{2} \mathrm{Ti}$ calcd.: $\mathrm{C}, 65.02 ; \mathrm{H}$, 8.18\%.

An analogous procedure gave the trimethylsilyl-substituted ansa-titanocene derivatives rac- and meso-2- $\mathrm{TiCl}_{2}$ in ratios of $0.6 / 1$ to $1.8 / 1$ and total yields of 45-50\%. Identification as 2- $\mathrm{TiCl}_{2}$ was from the ${ }^{1} \mathrm{H}$ NMR spectra (Tab. 1) and elemental analysis. Found: $\mathrm{C}, 55.32 ; \mathrm{H}, 7.66 . \mathrm{C}_{22} \mathrm{H}_{36} \mathrm{Cl}_{2} \mathrm{Si}_{2} \mathrm{Ti}$ calcd.: $\mathrm{C}, 55.57 ; \mathrm{H}$, $7.63 \%$.

Recrystallisation from diethyl ether or $\mathrm{CH}_{2} \mathrm{Cl}_{2}$ /pentane or, more efficiently, flash chromatography on a silica gel column (J.T. Baker, No. 7024-1) with petroleum ether / diethyl ether $(8 / 1)$, which yielded two completely separated red product fractions (pure racemate in the first, pure meso product in the second elution band) allowed isolation of both isomers in crystalline form. Crystal structures were determined for rac-2-Ti( $\left.\mathrm{CH}_{3}\right)_{2}$ and meso-2- $\mathrm{TiCl}_{2}$ (see below).

3- $\mathrm{TiCl}_{2}$ and $4-\mathrm{TiCl}_{2}$ were obtained by analogous reactions of the respective di-Grignard compounds with $\mathrm{TiCl}_{3} \cdot 3 \mathrm{THF}$, in total yields of $40-45 \%$, and with $\mathrm{rac} /$ meso ratios close to 1 . In these cases, complete separation of the isomers by fractional crystallisation was not achieved. Identification by ${ }^{1} \mathrm{H}$ NMR spectra (Tab. 1) and, in the case of 3- $\mathrm{TiCl}_{2}$, from the elemental analysis. Found: $\mathrm{C}, 63.62 ; \mathrm{H}$, 7.83. $\mathrm{C}_{22} \mathrm{H}_{32} \mathrm{Cl}_{2}$ Ti calcd.: $\mathrm{C}, 63.63 ; \mathrm{H}, 7.77 \%$.

The preparations of 5- $\mathrm{TiCl}_{2}$ and of $6-\mathrm{TiCl}_{2}$ were carried out as described for those of $1-\mathrm{TiCl}_{2}$ and $2-\mathrm{TiCl}_{2}$, except that the products were taken up in diethyl ether and freed from by-product (mainly unreacted ligand) by chromatography on $\mathrm{Al}_{2} \mathrm{O}_{3}$ (Merck A60, activity I). The crude products (total yields $40-45 \%$ ) contained the racemic and meso isomers in ratios of $1.2 / 1$ to $2.2 / 1$. The racemic isomers were isolated by fractional crystallisation from diethyl ether, or by flash chromatography as described above. Identification was from the ${ }^{1} \mathrm{H}$ NMR spectra (Tab. 1) and, in the case of 5- $\mathrm{TiCl}_{2}$, from the mass spectrum (parent ion at $m / e$ 567-571 with appropriate isotope distribution), and from the elemental analysis: Found: $\mathrm{C}, 71.95$; $\mathrm{H}, 7.28 . \mathrm{C}_{34} \mathrm{H}_{40} \mathrm{Cl}_{2} \mathrm{Ti}$ calcd.: $\mathrm{C}, 71.96 ; \mathrm{H}, 7.11 \%$.

The identity of 6- $\mathrm{TiCl}_{2}$ was confirmed by its mass spectrum (parent ion at $\mathrm{m} / e$ 646-649 with appropriate isotope distribution) and by the results of an X-ray crystal structure determination (see section 5).

\section{Synthesis of $\left(\mathrm{CH}_{3}\right)_{4} \mathrm{C}_{2}\left(\mathrm{C}_{5} \mathrm{H}_{3} \mathrm{R}\right)_{2} \mathrm{ZrCl}_{2}$}

The ansa-zirconocene complexes $1-\mathrm{ZrCl}_{2}$ and $2-\mathrm{ZrCl}_{2}$ were obtained by procedures similar to those used for their Ti analogues, starting from the t-butyl and trimethylsilyl substituted di-Grignard compounds $1-\left(\mathrm{MgCl}_{2} \cdot 4 \mathrm{THF}\right.$ and 2$(\mathrm{MgCl})_{2} \cdot 4 \mathrm{THF}$ and equimolar amounts of $\mathrm{ZrCl}_{4}$ in THF. Reaction for 2 days at reflux temperature, evaporation of solvent, extraction of the residue with diethyl ether, partial evaporation and cooling to $-80^{\circ} \mathrm{C}$, afforded the products, as rac/meso mixtures $(1.5 / 1$ to $2 / 1)$, in $20-30 \%$ total yield. ${ }^{1} \mathrm{H} \mathrm{NMR}$-spectrally pure rac-1- $\mathrm{ZrCl}_{2}$ was isolated by recrystallisation from diethyl ether and subjected to an X-ray structure determination. Identification was from the ${ }^{1} \mathrm{H}$ NMR spectra (Tab. 1) and, for $1-\mathrm{ZrCl}_{2}$, from the elemental analysis. Found: $\mathrm{C}, 59.17 ; \mathrm{H}, 7.48 . \mathrm{C}_{24} \mathrm{H}_{36} \mathrm{Cl}_{2} \mathrm{Zr}$ calcd.: C, 59.23; H, 7.46\%. 


\section{Crystal structure determinations}

Space groups, cell parameters and X-ray diffraction intensities of suitable crystals of the following compounds were determined on a Syntex-P3 four-circle diffractometer (Mo- $K_{\alpha}, \lambda 71.069 \mathrm{pm}$, graphite monochromator, $\omega$-scan with $\Delta \omega 1^{\circ}$ and $2.0 \leq \dot{\omega} \leq 29.3^{\circ} \mathrm{min}^{-1} ; 4.0^{\circ} \leq 2 \theta \leq 48^{\circ}$ for $\operatorname{rac}-2-\mathrm{Ti}\left(\mathrm{CH}_{3}\right)_{2}, \leq 50^{\circ}$ for rac-6-TiCl${ }_{2}$ and $\leq 52^{\circ}$ for rac-1- $\mathrm{ZrCl}_{2}$ and meso-2-TiCl${ }_{2}$ ).

The crystals of rac-1- $\mathrm{ZrCl}_{2}$, examined at $233 \mathrm{~K}$, were monoclinic, space group $C 2 / c$, with a 2036.1(4), b 989.7(2), c 1561.3(3) pm, $\beta$ 131.69(1) ${ }^{\circ} ; V 2349 \times 10^{6}$ $\mathrm{pm}^{3} ; 4$ crystallographically equivalent molecules per unit cell; $d_{\text {calcd }} 1.38 \mathrm{~g} / \mathrm{cm}^{3}$. For resolution and refinement of the structure, 2252 independent reflections with $I>1.5 \sigma(I)$ were used, without absorption corrections. The structure was solved by the Patterson method (SHELXTL); the $\mathrm{Zr}$ atom is situated on a crystallographic $C_{2}$ axis. Refinement with a partially anisotropic model converged at $R_{1} * 0.038$ and $R_{2} * 0.0435$ (H atoms in calculated positions). Structural parameters for rac-1- $\mathrm{ZrCl}_{2}$ are represented in Tab. 7 .

The crystals of rac-2-Ti $\left(\mathrm{CH}_{3}\right)_{2}$, examined at $238 \mathrm{~K}$, were also monoclinic, space group C2\%c, with $a 665.6(2), b 1907.3(8), c 1951.7(8) \mathrm{pm}, \beta 90.23(3)^{\circ} ; V 2477 \times 10^{6}$ $\mathrm{pm}^{3} ; 4$ crystallographically equivalent molecules per unit cell; $d_{\text {caicd }} 1.17 \mathrm{~g} / \mathrm{cm}^{3}$. For resolution and refinement of the structure, 1768 independent reflections with $I>1.5 \sigma(I)$ were used, without absorption corrections. The structure was solved by direct methods (SHELXTL); the Ti atom is situated on a crystallographic $C_{2}$ axis. Refinement with a partially anisotropic model converged at $R_{1} * 0.0344$ and $R_{2} *$ 0.0376 ( $\mathrm{H}$ atoms in calculated positions). Structural parameters for rac-2-Ti( $\left.\mathrm{CH}_{3}\right)_{2}$ are presented in Tab. 8.

\section{Table 7}

Structural parameters for $R, S-\left(\mathrm{CH}_{3}\right)_{4} \mathrm{C}_{2}\left(1-\mathrm{C}_{5} \mathrm{H}_{3}-3 \mathrm{C}\left(\mathrm{CH}_{3}\right)_{3}\right)_{2} \mathrm{ZrCl}_{2}$ (rac-1- $\left.\mathrm{ZrCl}_{2}\right)$, fractional coordinates $\left(\times 10^{4}\right.$, with e.s.d.'s) and isotropic thermal parameters $\left(\dot{\mathrm{A}}^{2} \times 10^{3}\right)$

\begin{tabular}{lrrll}
\hline & $x$ & $y$ & \multicolumn{1}{c}{$z$} & $U^{a}$ \\
\hline $\mathrm{Zr}(1)$ & 0 & $5203(1)$ & 7500 & $23(1)$ \\
$\mathrm{Cl}(1)$ & $-420(1)$ & $6792(1)$ & $6006(1)$ & $58(1)$ \\
$\mathrm{C}(1)$ & $823(2)$ & $3103(3)$ & $7847(2)$ & $23(2)$ \\
$\mathrm{C}(2)$ & $940(2)$ & $3979(3)$ & $7241(3)$ & $23(2)$ \\
$\mathrm{C}(3)$ & $1478(2)$ & $5090(3)$ & $7945(3)$ & $24(2)$ \\
$\mathrm{C}(4)$ & $1657(2)$ & $4929(3)$ & $8980(3)$ & $26(2)$ \\
$\mathrm{C}(5)$ & $1255(2)$ & $3728(3)$ & $8924(2)$ & $25(2)$ \\
$\mathrm{C}(6)$ & $377(2)$ & $1718(3)$ & $7480(3)$ & $28(2)$ \\
$\mathrm{C}(7)$ & $1093(2)$ & $669(3)$ & $8310(4)$ & $42(3)$ \\
$\mathrm{C}(8)$ & $36(2)$ & $1361(4)$ & $6284(3)$ & $38(2)$ \\
$\mathrm{C}(9)$ & $1935(2)$ & $6123(3)$ & $7769(3)$ & $28(2)$ \\
$\mathrm{C}(10)$ & $1878(3)$ & $7545(4)$ & $8097(4)$ & $41(3)$ \\
$\mathrm{C}(11)$ & $1546(3)$ & $6126(4)$ & $6523(3)$ & $47(3)$ \\
$\mathrm{C}(12)$ & $2906(2)$ & $5702(4)$ & $8561(4)$ & $46(3)$ \\
\hline
\end{tabular}

${ }^{a}$ Equivalent isotropic $U$ defined as one third of the trace of the orthogonalised $U_{i j}$ tensor.

$\bar{*}_{R_{1}}=\left(\Sigma|| F_{\mathrm{o}}|-| F_{\mathrm{c}} \|\right) / \Sigma\left|F_{\mathrm{o}}\right|$ and $R_{2}=\left[\Sigma \omega\left(\left|F_{\mathrm{o}}\right|-\left|F_{\mathrm{c}}\right|\right)^{2}\right]^{1 / 2} /\left[\Sigma \omega\left|F_{\mathrm{o}}\right|^{2}\right]^{1 / 2}$ 
Table 8

Structural parameters for $R, S-\left(\mathrm{CH}_{3}\right)_{4} \mathrm{C}_{2}\left(1-\mathrm{C}_{5} \mathrm{H}_{3}-3-\mathrm{Si}\left(\mathrm{CH}_{3}\right)_{3}\right)_{2} \mathrm{Ti}\left(\mathrm{CH}_{3}\right)_{2}$ (rac-2-Ti( $\left.\left(\mathrm{CH}_{3}\right)_{2}\right)$, fractional coordinates $\left(\times 10^{4}\right.$, with e.s.d.'s) and isotropic thermal parameters $\left(\dot{\AA}^{2} \times 10^{3}\right)$

\begin{tabular}{lrrll}
\hline & $x$ & $y$ & $z$ & $U^{a}$ \\
\hline Ti & 0 & $2037(1)$ & 2500 & $20(1)$ \\
$\mathrm{C}(1)$ & $2188(4)$ & $1241(2)$ & $2268(1)$ & $43(1)$ \\
$\mathrm{C}(2)$ & $-757(4)$ & $2621(1)$ & $3563(1)$ & $25(1)$ \\
$\mathrm{C}(3)$ & $359(4)$ & $2015(1)$ & $3751(1)$ & $25(1)$ \\
$\mathrm{C}(4)$ & $2278(3)$ & $2108(1)$ & $3462(1)$ & $26(1)$ \\
$\mathrm{C}(5)$ & $2331(4)$ & $2747(1)$ & $3110(1)$ & $26(1)$ \\
$\mathrm{C}(6)$ & $443(4)$ & $3085(1)$ & $3179(1)$ & $24(1)$ \\
$\mathrm{C}(7)$ & $-121(4)$ & $3803(1)$ & $2905(1)$ & $28(1)$ \\
$\mathrm{C}(8)$ & $-2268(4)$ & $3985(1)$ & $3129(1)$ & $37(1)$ \\
$\mathrm{C}(9)$ & $1258(5)$ & $4351(1)$ & $3252(1)$ & $42(1)$ \\
$\mathrm{Si}$ & $-227(1)$ & $1341(1)$ & $4414(1)$ & $27(1)$ \\
$\mathrm{C}(10)$ & $-2976(4)$ & $1230(2)$ & $4540(2)$ & $50(1)$ \\
$\mathrm{C}(11)$ & $1005(5)$ & $496(2)$ & $4185(2)$ & $47(1)$ \\
$\mathrm{C}(12)$ & $890(5)$ & $1661(2)$ & $5235(1)$ & $50(1)$ \\
\hline
\end{tabular}

${ }^{a}$ Equivalent isotropic $U$ defined as one third of the trace of the orthogonalised $U_{i j}$ tensor.

Table 9

Structural parameters for meso- $\left(\mathrm{CH}_{3}\right)_{4} \mathrm{C}_{2}\left(1-\mathrm{C}_{5} \mathrm{H}_{3}-3-\mathrm{Si}\left(\mathrm{CH}_{3}\right)_{3}\right){ }_{2} \mathrm{TiCl}_{2}$ (meso-2- $\mathrm{TiCl}_{2}$ ), fractional coordinates $\left(\times 10^{4}\right.$, with e.s.d.'s) and isotropic thermal parameters $\left(\AA^{2} \times 10^{3}\right)$

\begin{tabular}{lllll}
\hline & $x$ & $y$ & $z$ & $U^{a}$ \\
\hline $\mathrm{Ti}$ & $3984(1)$ & $6114(1)$ & $6233(1)$ & $15(1)$ \\
$\mathrm{Cl}(1)$ & $5982(1)$ & $5669(1)$ & $7256(1)$ & $27(1)$ \\
$\mathrm{Cl}(2)$ & $3643(1)$ & $6844(1)$ & $7683(1)$ & $27(1)$ \\
$\mathrm{Si}(1)$ & $2402(1)$ & $5487(1)$ & $8959(1)$ & $24(1)$ \\
$\mathrm{Si}(2)$ & $6748(1)$ & $7427(1)$ & $6176(1)$ & $21(1)$ \\
$\mathrm{C}(1)$ & $3946(5)$ & $5769(3)$ & $9948(4)$ & $37(2)$ \\
$\mathrm{C}(2)$ & $887(5)$ & $5961(3)$ & $9175(5)$ & $42(2)$ \\
$\mathrm{C}(3)$ & $2159(5)$ & $4651(3)$ & $9327(4)$ & $40(2)$ \\
$\mathrm{C}(4)$ & $2501(4)$ & $5506(2)$ & $7318(4)$ & $21(1)$ \\
$\mathrm{C}(5)$ & $3243(4)$ & $5094(2)$ & $6687(4)$ & $22(1)$ \\
$\mathrm{C}(6)$ & $2918(4)$ & $5199(2)$ & $5444(4)$ & $20(1)$ \\
$\mathrm{C}(7)$ & $1676(4)$ & $5860(2)$ & $6413(4)$ & $19(1)$ \\
$\mathrm{C}(8)$ & $1903(4)$ & $5672(2)$ & $5268(4)$ & $20(1)$ \\
$\mathrm{C}(9)$ & $1184(4)$ & $5907(2)$ & $4061(4)$ & $20(1)$ \\
$\mathrm{C}(10)$ & $-353(4)$ & $5935(2)$ & $4102(4)$ & $29(1)$ \\
$\mathrm{C}(11)$ & $1359(4)$ & $5428(2)$ & $3091(4)$ & $29(1)$ \\
$\mathrm{C}(12)$ & $1790(4)$ & $6562(2)$ & $3804(4)$ & $20(1)$ \\
$\mathrm{C}(13)$ & $1047(4)$ & $7090(2)$ & $4346(4)$ & $29(1)$ \\
$\mathrm{C}(14)$ & $1681(5)$ & $6689(2)$ & $2448(4)$ & $32(1)$ \\
$\mathrm{C}(15)$ & $4316(4)$ & $6134(2)$ & $4212(3)$ & $18(1)$ \\
$\mathrm{C}(16)$ & $3287(4)$ & $6584(2)$ & $4370(3)$ & $16(1)$ \\
$\mathrm{C}(17)$ & $5552(4)$ & $6333(2)$ & $4856(3)$ & $19(1)$ \\
$\mathrm{C}(18)$ & $3956(4)$ & $7051(2)$ & $5094(4)$ & $20(1)$ \\
$\mathrm{C}(19)$ & $5362(4)$ & $6905(2)$ & $5437(3)$ & $18(1)$ \\
$\mathrm{C}(20)$ & $7368(5)$ & $7871(2)$ & $4967(4)$ & $38(2)$ \\
$\mathrm{C}(21)$ & $8183(4)$ & $6946(2)$ & $6937(4)$ & $35(2)$ \\
$\mathrm{C}(22)$ & $6072(5)$ & $7983(2)$ & $7183(4)$ & $32(1)$ \\
\hline
\end{tabular}

${ }^{a}$ Equivalent isotropic $U$ defined as one third of the trace of the orthogonalised $U_{i j}$ tensor. 
Table 10

Structural parameters for $R, S-\left(\mathrm{CH}_{3}\right)_{4} \mathrm{C}_{2}\left(1-\mathrm{C}_{5} \mathrm{H}_{3}-3-\mathrm{C}_{2}\left(\mathrm{CH}_{2}\right)_{5} \mathrm{C}_{6} \mathrm{H}_{5}\right)_{2} \mathrm{TiCl}_{2}$ (rac-6-TiCl 2 ), fractional coordinates $\left(\times 10^{4}\right.$, with e.s.d.'s) and isotropic thermal parameters $\left(\AA^{2} \times 10^{3}\right)$

\begin{tabular}{|c|c|c|c|c|}
\hline & $x$ & $y$ & $z$ & $U^{a}$ \\
\hline$\overline{T i(1)}$ & $5208(1)$ & $3123(1)$ & $1175(1)$ & $20(1)$ \\
\hline $\mathrm{Cl}(1)$ & 2192(1) & 2971(1) & $1190(1)$ & $35(1)$ \\
\hline $\mathrm{Cl}(2)$ & $5072(1)$ & $4511(1)$ & $1002(1)$ & 41(1) \\
\hline$C(1)$ & $4825(4)$ & $2009(2)$ & $609(1)$ & $26(1)$ \\
\hline$C(2)$ & $4766(4)$ & $2720(2)$ & $317(1)$ & $23(1)$ \\
\hline$C(3)$ & $6364(4)$ & $3112(2)$ & $397(1)$ & $27(1)$ \\
\hline C(4) & $7400(4)$ & $2649(2)$ & $719(1)$ & $28(1)$ \\
\hline$C(5)$ & $6454(4)$ & $1944(2)$ & $850(1)$ & $27(1)$ \\
\hline$c(6)$ & $7120(4)$ & $1253(2)$ & $1178(1)$ & $33(1)$ \\
\hline$C(7)$ & $6646(5)$ & $420(2)$ & $952(1)$ & 41(1) \\
\hline$C(8)$ & $9115(4)$ & $1266(2)$ & $1213(2)$ & $42(1)$ \\
\hline $\mathrm{C}(9)$ & $6349(5)$ & $1364(2)$ & $1679(1)$ & $34(1)$ \\
\hline $\mathrm{C}(10)$ & $7420(6)$ & $954(2)$ & $2084(1)$ & $47(1)$ \\
\hline C(11) & $4539(5)$ & $974(2)$ & $1681(1)$ & $44(1)$ \\
\hline$C(12)$ & $6214(4)$ & $2276(2)$ & $1787(1)$ & $29(1)$ \\
\hline C(13) & $7504(4)$ & $2888(2)$ & $1742(1)$ & $25(1)$ \\
\hline$C(14)$ & $6893(4)$ & $3651(2)$ & $1893(1)$ & $24(1)$ \\
\hline$C(15)$ & $5170(4)$ & $3525(2)$ & 2011(1) & $29(1)$ \\
\hline$C(16)$ & $4792(4)$ & $2684(2)$ & $1966(1)$ & $31(1)$ \\
\hline$C(17)$ & $3405(4)$ & $2973(2)$ & $-66(1)$ & $23(1)$ \\
\hline$C(18)$ & $2953(4)$ & 3893(1) & $-8(1)$ & $27(1)$ \\
\hline$C(19)$ & $1537(4)$ & $4182(2)$ & $-367(1)$ & $32(1)$ \\
\hline $\mathrm{C}(20)$ & $-63(4)$ & $3674(2)$ & $-326(1)$ & $41(1)$ \\
\hline$C(21)$ & $309(4)$ & $2768(2)$ & $-384(1)$ & $39(1)$ \\
\hline $\mathrm{C}(22)$ & $1732(4)$ & $2474(2)$ & $-27(1)$ & $31(1)$ \\
\hline$C(23)$ & $4241(4)$ & $2796(2)$ & $-546(1)$ & $24(1)$ \\
\hline$C(24)$ & $5074(4)$ & $3408(2)$ & $-786(1)$ & $35(1)$ \\
\hline $\mathrm{C}(25)$ & $5824(5)$ & $3252(2)$ & $-1214(1)$ & $42(1)$ \\
\hline$C(26)$ & $5775(5)$ & $2475(3)$ & $-1411(1)$ & $44(1)$ \\
\hline$C(27)$ & $4975(5)$ & $1865(3)$ & $-1173(1)$ & $50(1)$ \\
\hline $\mathrm{C}(28)$ & $4228(5)$ & $2016(2)$ & $-745(1)$ & $40(1)$ \\
\hline C(29) & $8003(4)$ & $4406(2)$ & 1996(1) & $24(1)$ \\
\hline$C(30)$ & $9184(4)$ & $4596(2)$ & $1586(1)$ & $27(1)$ \\
\hline $\mathrm{C}(31)$ & $10295(5)$ & $5355(2)$ & $1679(1)$ & $39(1)$ \\
\hline $\mathrm{C}(32)$ & $9231(5)$ & $6103(2)$ & $1778(1)$ & $45(1)$ \\
\hline$C(33)$ & $8009(5)$ & $5941(2)$ & $2179(1)$ & $38(1)$ \\
\hline$C(34)$ & $6906(4)$ & $5179(2)$ & $2077(1)$ & $33(1)$ \\
\hline$C(35)$ & $9053(4)$ & $4150(2)$ & $2455(1)$ & $25(1)$ \\
\hline$C(36)$ & $10634(4)$ & $3767(2)$ & $2440(1)$ & $34(1)$ \\
\hline$C(37)$ & $11490(5)$ & $3484(2)$ & 2851(1) & $42(1)$ \\
\hline$C(38)$ & $10784(5)$ & $3575(2)$ & $3286(1)$ & $44(1)$ \\
\hline$C(39)$ & $9223(5)$ & $3953(3)$ & $3303(1)$ & $50(1)$ \\
\hline$C(40)$ & $8355(5)$ & $4234(2)$ & $2898(1)$ & $39(1)$ \\
\hline$O(1)$ & 0 & 0 & 0 & $142(4)$ \\
\hline$C(41)$ & $675(10)$ & $-503(5)$ & $232(3)$ & $54(3)$ \\
\hline$C(42)$ & $2368(15)$ & $-226(9)$ & $450(4)$ & $70(5)$ \\
\hline $\mathrm{C}(51)$ & $1643(16)$ & $0(7)$ & $253(4)$ & $73(5)$ \\
\hline $\mathrm{C}(52)$ & $2548(15)$ & $-788(7)$ & $370(4)$ & $68(4)$ \\
\hline
\end{tabular}

${ }^{a}$ Equivalent isotropic $U$ defined as one third of the trace of the orthogonalised $U_{i j}$ tensor. 
The crystals of meso-2- $\mathrm{TiCl}_{2}$, examined at $225 \mathrm{~K}$, were monoclinic, space group $P 21 / c$ with $a$ 997.7(3), b 2161.3(5), $c$ 1132.3(4) pm, $\beta$ 98.76(3) ${ }^{\circ} ; V 2413 \times 10^{6}$ $\mathrm{pm}^{3} ; 4$ crystallographically equivalent molecules per unit cell; $d_{\text {calcd }} 1.15 \mathrm{~g} / \mathrm{cm}^{3}$. For resolution and refinement of the structure, 4548 independent reflections with $I>1.5 \sigma(I)$ were used, without absorption corrections. The structure was solved by the Patterson method (SHELXTL). Refinement with a partially anisotropic model (deleting reflections 100,130 and -121 ) converged at $R_{1} 0.0669$ and $R_{2} 0.0707$ ( $\mathrm{H}$ atoms in calculated positions). Structural parameters for $m e s o-2-\mathrm{TiCl}_{2}$ are presented in Tab. 9.

Crystals of rac-6- $\mathrm{TiCl}_{2}$, examined at $246 \mathrm{~K}$, were monoclinic, space group $P 2_{1} / c$, with $a 782.5(2), b 1629.3(5), c 2817.0(8) \mathrm{pm}, \beta 92.91(2)^{\circ} ; V 3587 \times 10^{6} \mathrm{pm}^{3} ; 4$ crystallographically equivalent molecules per unit cell; $d_{\text {calcd }} 1.27 \mathrm{~g} / \mathrm{cm}^{3}$. For resolution and refinement of the structure, 5269 independent reflections with $I>1.5 \sigma(I)$ were used, without absorption corrections. The structure was solved by direct methods (SHELXTL). Half a molecule of diethyl ether was found per unit cell, partially disordered, with its $O$ atom located on a crystallographic inversion center. Refinement with a partially anisotropic model converged at $R_{1} 0.0507$ and $R_{2} 0.0535$ ( $\mathrm{H}$ atoms in calculated positions). Structural parameters for rac-6- $\mathrm{TiCl}_{2}$ are represented in Table 10.

Structural data obtained for these four compounds are available on request from Fachinformationszentrum Energie Physik Mathematik, D-7514 EggensteinLeopoldshafen 2, upon quotation, of deposit number CSD 53634, the authors, and the Journal reference for this article.

\section{Acknowledgements}

Financial support for this study by Deutsche Forschungsgemeinschaft (grant Bri 510), by Fonds der Chemischen Industrie and by funds of the University of Konstanz is gratefully acknowledged.

\section{References}

1 E.U. van Raaij and H.H. Brintzinger, J. Organomet. Chem., 356 (1988) 315.

2 J.A. Ewen, J. Am. Chem. Soc., 106 (1984) 6355.

3 W. Kaminsky, K. Külper, H.H. Brintzinger and F.R.W.P. Wild, Angew. Chem., 97 (1985) 507.

4 K. Soga, T. Shiono, S. Takemura, W. Kaminsky, Makromol. Chem. Rapid Comm., 8 (1987) 305.

5 P. Pino, P. Cioni and J. Wei, J. Am. Chem. Soc., 109 (1987) 6189.

6 P. Corradini, G. Guerra, M. Vacatello and V. Villano, Gaz. Chim. Ital., 118 (1988) 173.

7 P. Longo, A. Grassi, C. Pellecchia and A. Zambelli, Macromolecules, 20 (1987) 1015; A. Grassi, A. Zambelli, L. Resconi, E. Albizzati and R. Mazzochi, Macromolecules 21 (1988) 617; A. Grassi, P. Amendola, P. Longo, E. Albizzati, L. Resconi and R. Mazzochi, Gaz. Chim. Ital., 118 (1988) 539.

8 F.R.W.P. Wild, L. Zsolnai, G. Huttner and H.H. Brintzinger, J. Organomet. Chem., 232 (1982) 233; F.R.W.P. Wild, M. Wasiucionek, G. Huttner and H.H. Brintzinger, J. Organomet. Chem., 288 (1985) 63.

9 J.A. Ewen, L. Haspeslagh, J.L. Atwood and H. Zhang, J. Am. Chem. Soc., 109 (1987) 6544; J.A. Ewen, L. Haspeslagh, M.J. Elder, J.L. Atwood, H. Zhang and H.N. Cheng, in W. Kaminsky and H. Sinn (Eds.), Olefin Polymerisation, Berlin, 1988, p. 281.

10 H. Schwemlein and H.H. Brintzinger, J. Organomet. Chem., 254 (1983) 69.

11 N. Klouras and H. Köpf, Monatsh. Chem., 112 (1981) 887; H. Köpf und N. Klouras, Z. Naturforsch. 38B (1983) 321. 
12 H. Wiesenfeldt, A. Reinmuth, E. Barsties, K. Evertz and H.H. Brintzinger, J. Organomet. Chem., 369 (1989) 359.

13 R. Riemschneider and R. Nehring, Monatsh. Chem., 90 (1959) 568.

14 K. Hafner, Ann. Chem., 606 (1957) 79; W.F. Little and R.C. Koestler, J. Org. Chem., 26 (1961) 3245; M.F. Sullivan and W.F. Little, J. Organomet. Chem., 8 (1967) 277.

15 C.S. Kraihanzel and M.L. Losee, J. Am. Chem. Soc., 90 (1968) 4701.

16 K.J. Stone and R.D. Little, J. Org. Chem., 49 (1984) 1849.

17 K. Ziegler and W. Schäfer, Ann. Chem., 511 (1934) 101.

18 G.R. Knox and P.L. Pauson, J. Chem. Soc. (1961) 4610.

19 O. Helmling and K. Hafner, unpublished work, 1978, quoted in K.P. Zeller, Pentafulvene, HoubenWeyl, Vol. V/2c, p. 528.

20 D.J. Sardella, C.M. Keane and P. Lemonias, J. Am. Chem. Soc., 106 (1984) 4962. 